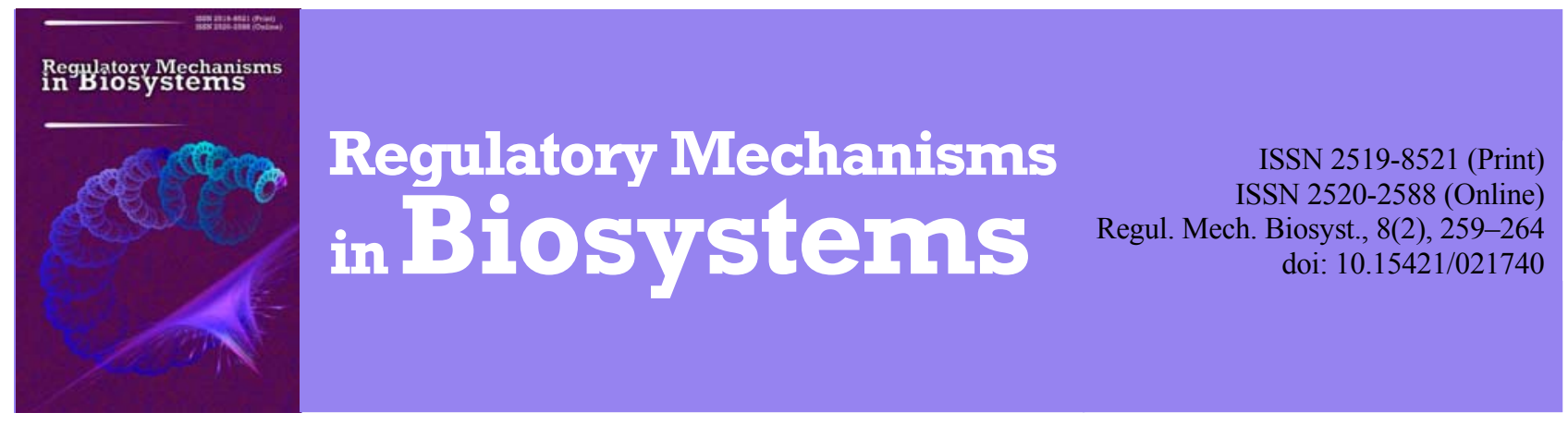

\title{
Molecular mechanisms of metabolic disorders in the organs of rats of different ages affected by sodium nitrite in the context of tobacco intoxication
}

\author{
P. H. Lyhatskyi, L. S. Fira, D. B. Fira, I. P. Kuzmak \\ I. Horbachevsky Ternopil State Medical University, Ternopil, Ukraine
}

Article info

Received 24.03.2017

Received in revised form 22.04.2017

Accepted 25.04.2017

I. Horbachevsky Ternopil State Medical University, majdan Voli, 1 ,

Ternopil, 46001, Ukraine. Tel.: +38-0352-524-492.

E-mail:ludafira@mail.ru
Lyhatskyi, P. H., Fira, L. S., Fira, D. B., \& Kuzmak, I. P. (2017). Molecular mechanisms of metabolic disorders in the organs of rats of different ages affected by sodium nitrite in the context of tobacco intoxication. Regulatory Mechanisms in Biosystems, 8(2), 259-264. doi:10.15421/021740

Among pollutants a significant threat is posed by heavy metals, nitrate fertilizers and industrial waste. However, people also contribute to this threat through bad habits such as smoking and alcohol. All these factors affect health and can cause death. The aim of this study was to investigate the content of reactive oxygen species, markers of cytolysis of hepatocytes, cardoza and the degree of endogenous intoxication in the organism of rats affected by nitrite of sodium on the background of tobacco intoxication. The experiments were carried out on white rats, which were divided into three age categories: immature, mature and old, who for 30 days were exposed to tobacco smoke. The research animals were divided into three groups. One of them for 24 hours before the end of the experiment was given sodium nitrite, the second group was given sodium nitrite 72 hours before the end of the experiment. 30 days after poisoning we tested the contents of reactive oxygen species in neutrophils, cytolysis of erythrocyte membrane was investigated by erythrocytic index of intoxication, hepatocytes and cardiocytes - aminotransferase activity. The degree of endogenous intoxication was evaluated by the content of average weight molecules in blood serum. Poisoning of rats with sodium nitrite in the background of the 30 day intoxication by tobacco smoke led to a significant formation of ROS in neutrophils of rats of different age groups. We investigated the activity of aminotransferases in the blood serum and the above organs of rats after exposing them to sodium nitrite and 30 day tobacco smoke. In the blood serum of adult and aged rats, the activity of alanine aminotransferase increased in these conditions by 2.1 and 1.6 times, respectively. Sodium nitrite, which was an additional factor in the intoxication of the rats of all age groups by smoke, caused more pronounced changes in the activity of the studied enzyme in the blood serum. In the liver and myocardium of rats of different ages was observed a reliable decrease of this index was observed in all experimental groups. Trere was a significant increase in the serum of rats at different ages of aspartate aminotransferase activity. Aspartate aminotransferase activity in the myocardium of all experimental animals showed a reduction by 1.2-1.3 times after smoke inhalation and 1.5-1.6 times with simultaneous intoxication of the rats by sodium nitrite and tobacco smoke. Sodium nitrite, as an additional toxin raised the penetration capacity of erythrocytes among rats poisoned with smoke.By the end of the experiment, the erythrocyte index of intoxication increased in all age groups: immature rats by $31.7 \%$, mature - by $36.0 \%$, in old rats - by $23.6 \%$. The next step of our research was to investigate the markers of endogenous intoxication - average molecular weight. After the simultaneous intoxication of rats by sodium nitrate and tobacco smoke, at the end of the experiment the content of average weight molecules was $\lambda=254$ and of average mass $\lambda=280$ in the blood serum of rats of all age groups increased by 3.1-3.3 times compared with the intact control group. Immature rats proved most sensitive to the action of sodium nitrite and tobacco.

\section{Молекулярні механізми метаболічних порушень в органах щурів різного віку, уражених натрію нітритом на тлі тютюнової інтоксикації}

\author{
П. Г. Лихацький, Л. С. Фіра, Д. Б. Фіра, І. П. Кузьмак
}

\author{
Тернопільський державний медичний університет імені І. Я. Горбачевського МОЗ Украйни, Тернопіль, Украӥна
}

Ураження щурів натрію нітритом на тлі 30-денної інтоксикації тютюновим димом зумовило посилене утворення активних форм кисню в нейтрофілах крові. Отруєння токсикованих димом щурів натрію нітритом протягом 72 год. спричинило значне збільшення вмісту активних форм кисню порівняно 3 інтактними тваринами. Найвиразніше збільшення вмісту активних форм кисню відмічене у статевонезрілих щурів (утричі). Ці сполуки проявляють деструктивний вплив на біомакромолекули в організмі, викликають цитоліз гепатоцитів, кардіоцитів та еритроцитів, про що свідчить збільшення активності амінотрансфераз у сироватці крові та зниження їх у печінці та міокарді. Встановлено підвищення активності амінотрансфераз у сироватці крові щурів усіх вікових груп - найчутливішими до 
цих показників виявились молоді особини. Аналогічно найвиразніше зниження активностей амінотрансфераз спостерігали у печінці та міокарді статевонезрілих тварин. Протягом дослідження відмічено збільшення проникності еритроцитарних мембран щурів усіх вікових категорій. До кінця експерименту проникність еритроцитарної мембрани виразно збільшилась у молодих і статевозрілих щурів. Еритроцитарні мембрани старих тварин виявились найстійкішими до дії токсичних чинників. За ураження щурів тютюновим димом і натрію нітритом посилюються катаболічні процеси та поглиблюється ендогенна інтоксикація, маркери якої - молекули середньої маси. За одночасного ураження тварин обома токсикантами у сироватці крові спостерігається значне збільшення вмісту молекул середньої маси обох фракцій (фракція $\mathrm{CM}_{1}$, в якій переважають ланцюгові амінокислоти, та фракція $\mathrm{CM}_{2}$, в якій переважають ароматичні амінокислоти). Збільшення вмісту молекул середньої маси в сироватці крові тварин усіх вікових груп виявилось на одному рівні. Найчутливіші до дії тютюнового диму та нітриту натрію виявились статевонезрілі особини.

Ключові слова: активні форми кисню; амінотрансферази; ендогенна інтоксикація; молекули середньої маси

\section{Вступ}

Тютюновий дим належить до найагресивніших «прооксидантних полютантів». Крім нікотину, в організм людини надходять понад 4000 різних токсичних речовин. У газоподібній частині тютюнового диму містяться такі високотоксичні хімічні компоненти як ціанистий водень, метан, летючі нітрати, окис азоту, анілін, толуоїдин, деякі поліциклічні ароматичні сполуки вуглецю, низка окиснених сполук - альдегідів, фенолів, кислот, складних эфірів (Wipfli and Samet, 2009; Pappas, 2011; Behera et al., 2014). Агресивність диму зумовлена не тільки газоподібними хімічними активними сполуками, яким властива канцерогенна дія (формальдегід, бензпірен), а й елементами твердої фази цигаркового диму (сполуками кадмію, нікелю, полонію, деякими іншими важкими металами) (Hagstad et al., 2014; Shihadeh et al., 2015; Pikas, 2015).

Отримано також свідчення про те, що не тільки активне паління, а й забруднення атмосфери приміщень тютюновим димом - фактор ризику у виникненні різних захворювань (Stangherlin et al., 2009; Hagstad et al., 2014).

Під час куріння відбувається генерація активних форм кисню $\left(\mathrm{O}_{2}^{-}, \mathrm{O}_{2}^{1-}, \mathrm{OH}^{-}, \mathrm{RO}_{2}, \mathrm{OH}_{2}, \mathrm{H}_{2} \mathrm{O}_{2}\right.$ тощо), які відіграють важливу роль у багатьох фізіологічних (Valavanidis et al., 2009; Westbrook et al., 2010) i біохімічних процесах: регуляції тонусу судин, клітинній проліферації, синтезі простагландинів, передачі сигналів від міжклітинних сигнальних молекул на регуляторні системи, що контролюють експресію генів, мікробоцидній дії фагоцитів (Varela-Carver et al., 2010; Ignatowicz et al., 2012).

В основі патогенної дії забрудненого полютантами або тютюновим димом повітря лежить оксидантна агресія на слизову оболонку дихальних шляхів активними формами кисню, діоксидами азоту та сірки, іншими вільними радикалами (Churg et al., 2008; Halima et al., 2009; Luchese et al., 2009), що викликає активацію перекисного окиснення ліпідів і пошкодження біологічних мембран (Ray et al., 2012; Pickering et al., 2013).

У зв'язку з широким використанням нітратних добрив у сільському господарстві та їх міграцією у грунтові води та харчові продукти поширення нітратних отруєнь набуло епідемічного значення. Підвищений вміст нітратів у продуктах став реальним фактом сучасного життя.

Літературні дані свідчать, що за гемічної гіпоксії, спричиненої введеним натрію нітритом (Yrhashev, 2009; Jensen, 2010; Buehler etal., 2011), у тканинах тварин простежується нагромадження рівня активних форм кисню та інтенсифікація процесів ПОЛ. Нітритна інтоксикація супроводжується вираженим мембранотоксичним ефектом (El-Sheikh and Khalil, 2011; Ivanov et al., 2014; Baek et al., 2015). У реальному житті нерідко зустрічається комбінована дія декількох токсичних чинників на організм. Повсякденно людина піддається впливу цих речовин.

Мета нашого дослідження - оцінити вміст активних форм кисню, маркери цитолізу гепатоцитів, кардіоцитів і ступінь ендогенної інтоксикації в організмі щурів, уражених нітритом натрію на тлі тютюнової інтоксикації.

\section{Матеріал і методи досліджень}

Для проведення досліджень використовували білих безпородних щурів-самців, яких утримували на стандартному раціоні віварію Тернопільського державного медичного університету. Щури поділені на три вікові категорії: перша - статевонезрілі, масою тіла 60-80 г, друга - статевозрілі, масою тіла 180-200 г, третя - старі щури, масою тіла 300-320 г. Кожна вікова група складалася із двох підгруп: інтактний контроль і дослідна група. Щурів дослідних груп протягом 30 діб піддавали впливу тютюнового диму. Дослідні тварини поділені ще на три групи. Одній із них за 24 год. до закінчення експерименту вводили натрію нітрит у дозі 45 мг/кг маси тіла, другій - натрію нітрит (за 72 год. до евтаназіi). Третю групу щурів піддавали токсичному впливу тільки тютюнового диму. Модель залежності від хронічної дії тютюнового диму створювали за допомогою герметичної камери об'ємом 30 л, що дозволило обкурювати тварин у вільних умовах. Тютюновий дим, що утворювався під час горіння шести сигарет «Прима срібна (синя)» (з умістом 0,6 мг нікотину та 8 мг смоли), через отвори в камері подавали всередину. У камері одночасно перебували шість тварин протягом 6 хвилин. Тварин контрольної групи також розміщували протягом 6 хвилин у герметичній камеpi, але не підлягали дії тютюнового диму.

Через 30 діб після початку ураження тварин тютюновим димом їх виводили 3 експерименту шляхом евтаназії під тіопенталовим наркозом.

Для дослідження брали кров, сироватку крові, печінку та міокард тварин. Із дослідних тканин готували $10 \%$ гомогенат на фізіологічному розчині.

Вміст активних форм кисню (АФК) визначали в нейтрофілах крові методом Maruschak (2012). Популяцію нейтрофілів крові отримували за допомогою центрифугування на подвійному градієнті щільності 1,077 і 1,093 фіколу-верографіну. Після 40 хв центрифугування за температури $4{ }^{\circ} \mathrm{C}$ і швидкості 1500 об./хв утворювалися дві інтерфази. Верхня інтерфаза (на межі «плазма - верифікол», щільністю 1,077) складалася 3 мононуклеарних клітин: $80 \%$ лімфоцитів, $15-18 \%$ моноцитів і незначного (2-3\%) додатка гранулоцитів. Нижня інтерфаза (на межі градієнтів розчинів щільністю $1,077-1,092$ ) являла собою на $98-100 \%$ популяцію нейтрофілів. Життєздатність клітин у тесті з трипановим синім складала 98-99\%. Аналіз зразків клітин для визначення АФК нейтрофілів проводився на проточному цитометрі Epics XL (Beckman Coulter, CША) 3 допомогою 2,7-дигідродихлорфлюоресцеїн діацетату. Значення досліджуваного параметра виражали у відсотках (інтенсивність світіння на клітину). Цитоліз еритроцитарної мембрани досліджували за еритроцитарним індексом інтоксикації (ЕII) (Tohaybaev et al., 1988), гепатоцитів і кардіоцитів - за активністю амінотрансфераз (АсAТ і АлАТ) в реакції з 2,4-динітрофенілгідразином (Reitman and Frankel, 1957; Tarrant et al., 2013). Ступінь ендогенної інтоксикації оцінювали за вмістом молекул середньої маси (МСM) у сироватці крові, зокрема двох фракцій $\left(\mathrm{CM}_{1}\right.$ i CM 2$)($ Nikolaichik, 1989; Winchester and Audia, 2006).

Під час проведення досліджень користувались загальними принципами експериментів на тваринах, схваленими на Національному конгресі з біоетики (Київ, Україна, 2001) та узгодженими з положеннями Європейської конвенції про захист хребетних тварин, яких використовують для експериментальних та інших наукових цілей (Страсбург, Франція, 1985) (Simon and Wilkinson, 2007; Gross and Tolba, 2015). Статистичну обробку даних проводили за допомогою програми Statistica 6.03 використанням параметричного критерію ANOVA та непара- 
метричного критерію Вілкоксона для зв'язаних вибірок. Зміни вважали достовірними за $\mathrm{P}<0,05$.

\section{Результати}

Отруєння натрію нітритом на тлі 30-добової інтоксикації тютюновим димом викликало значне утворення активних форм кисню в нейтрофілах крові щурів різних вікових груп (табл. 1).

Найчутливішими до дії токсиканта виявились статевонезрілі щури, в яких уміст активних форм кисню у крові збільшився у 2,6 раза, менш чутливими - старі особини (даний показник перевищував рівень інтактних тварин у 2,1 раза). У статевозрілих щурів вміст активних форм кисню лише в 1,6 раза перевищував норму. Після потрапляння до організму додаткового токсиканта натрію нітриту рівень досліджуваного показника значно підвищувався. На 30-ту добу тютюнової інтоксикацї та 24 год. отруєння натрію нітритом вміст активних форм кисню виявився дещо вищим порівняно з таким у щурів, яких піддавали тільки впливу тютюнового диму. Ураження токсикованих димом щурів натрію нітритом протягом 72 год. зумовило значне збільшення вмісту активних форм кисню порівняно з інтактними тваринами. У статевонезрілих щурів цей показник збільшився утричі, у статевозрілих і старих - у 2,0 та 2,6 раза, відповідно.

Очевидно, таке підвищення концентрації активних форм кисню - наслідок зміщення рівноваги між процесами їх утворення та детоксикації та може бути передумовою порушення функціональної активності клітин, розвитку патологічних процесів в організмі.

\section{Таблиця 1}

Вміст активних форм кисню (\%) у нейтрофілах крові щурів різного віку, уражених натрію нітритом, на тлі 30-добової інтоксикації тютюновим димом $(\mathrm{M} \pm \mathrm{m} ; \mathrm{n}=6)$

\begin{tabular}{|c|c|c|c|}
\hline \multirow{2}{*}{ Термін дослідження } & \multicolumn{3}{|c|}{ Групи дослідних тварин } \\
\hline & статевонезрілі & статевозрілі & старі \\
\hline Інтактні щури & $15,06 \pm 0,71$ & $18,47 \pm 0,22$ & $19,87 \pm 0,86$ \\
\hline 30-та доба ураження тютюновим димом & $39,25 \pm 1,29 * * *$ & $29,54 \pm 0,50 * * *$ & $41,89 \pm 0,78^{* * *}$ \\
\hline 30-та доба ураження тютюновим димом + 24 год. отруєння натрію нітритом & $43,52 \pm 1,47 * * *$ & $32,53 \pm 0,74 * * *$ & $46,47 \pm 0,53 * * *$ \\
\hline 30-та доба ураження тютюновим димом + 72 год. отруєння натрію нітритом & $45,78 \pm 0,84 *$ & $37,86 \pm 0,67 * * *$ & $52,18 \pm 1,20 * * *$ \\
\hline
\end{tabular}

Примітка: вірогідні зміни між інтактними щурами та щурами, ураженими токсикантами: * - $\mathrm{P}<0,05, * *$ - $<<0,01, * * *$ - $<<0,001$.

Важлива частина наших досліджень - оцінювання деструктивних процесів в уражених обраними токсичними речовинами тканинах. Ми дослідили активність амінотрансфераз маркерних ензимів печінки та міокарда в сироватці крові та вищеназваних органах щурів після одночасного ураження їх натрію нітритом та тютюновим димом (табл. 2, 3).

За 30-добового ураження тютюновим димом найбільші зміни активності аланінамінотрансферази відмічені у сироватці крові статевонезрілих щурів: цей показник у них збільшився у 4,5 раза, порівняно 3 рівнем у інтактних щурів. У сироватці крові статевозрілих і старих щурів активність аланінамінотрансферази збільшилась за даних умов у 2,1 та 1,6 раза, відповідно. Натрію нітрит, який отримали отруєні димом щури всіх вікових груп, викликав сильні зміни активності досліджуваного ензиму у сироватці крові. Через 72 год. після його потрапляння до організму ензим підвищив активність у 6,5 раза у статевонезрілих щурів і в 2,9 раза у двох інших групах тварин (табл. 2). У печінці та міокарді щурів різного віку спостерігали вірогідне зниження цього показника в усіх дослідних групах. Найвираженіше зниження активності ала- нінамінотрансферази відмічене у печінці старих щурів, які отримували обидва токсиканти, а термін дослідження становив 72 год. отруєння натрію нітритом на тлі 30-добової інтоксикації тютюновим димом. У міокарді щурів усіх дослідних груп зниження активності аланінамінотрансферази становило близько $50 \%$.

Під час дослідження активності аспартатамінотрансферази виявлено аналогічні зміни. У сироватці крові щурів різного віку активність ензиму зазнала значного підвищення (табл. 3). Найчутливішими виявились старі щури. Цей показник у них підвищився після отруєння димом утричі, а наприкінці дослідження під час ураження обома токсикантами - уп'ятеро. Вірогідне збільшення (P < 0,001) активності досліджуваного ензиму відмічене й у двох інших вікових групах.

У печінці щурів після інтоксикації тютюновим димом відмічали зниження активності аспартатамінотрансферази у 1,7, 1,6 та 1,4 раза відповідно у статевонезрілих, статевозрілих і старих щурів. В останній термін дослідження впливу обох токсикантів активність ензиму знизилась у 2,5 раза у печінці щурів різних вікових груп.

\section{Таблиця 2}

Активність аланінамінотрансферази у сироватці крові (мкмоль/л год.), печінці та міокарді (мкмоль/кг год.) щурів різного віку, уражених натрію нітритом, на тлі 30 -добової інтоксикації тютюновим димом $(\mathrm{M} \pm \mathrm{m}, \mathrm{n}=6)$

\begin{tabular}{|c|c|c|c|c|}
\hline \multirow{2}{*}{$\begin{array}{l}\text { Дослідні } \\
\text { зразки }\end{array}$} & \multirow{2}{*}{ Термін дослідження } & \multicolumn{3}{|c|}{ Групи дослідних тварин } \\
\hline & & статевонезрілі & статевозрілі & старі \\
\hline \multirow{4}{*}{$\begin{array}{l}\text { Сироватка } \\
\text { крові }\end{array}$} & Інтактні щури & $0,56 \pm 0,02$ & $1,10 \pm 0,11$ & $1,45 \pm 0,12$ \\
\hline & 30-та доба ураження тютюновим димом & $2,52 \pm 0,19 * * *$ & $2,36 \pm 0,14 * * *$ & $2,27 \pm 0,20 * * *$ \\
\hline & $\begin{array}{l}30 \text {-та доба ураження тютюновим димом + } \\
24 \text { год. отруєння натрію нітритом }\end{array}$ & $3,03 \pm 0,18 * * *$ & $2,76 \pm 0,16^{* * *}$ & $3,41 \pm 0,24 * * *$ \\
\hline & $\begin{array}{l}\text { 30-та доба ураження тютюновим димом + } \\
72 \text { год. отруєння натрію нітритом }\end{array}$ & $3,62 \pm 0,31 * * *$ & $3,15 \pm 0,21 * * *$ & $4,17 \pm 0,37 * * *$ \\
\hline \multirow{4}{*}{ Печінка } & Інтактні щури & $6,98 \pm 0,10$ & $6,60 \pm 0,27$ & $8,03 \pm 0,28$ \\
\hline & 30-та доба ураження тютюновим димом & $4,26 \pm 0,28 * * *$ & $4,65 \pm 0,46^{* * *}$ & $4,02 \pm 0,39 * * *$ \\
\hline & $\begin{array}{l}30 \text {-та доба ураження тютюновим димом + } \\
24 \text { год. отруєння натрію нітритом }\end{array}$ & $3,37 \pm 0,26^{* * *}$ & $3,74 \pm 0,27 * * *$ & $2,66 \pm 0,14 * * *$ \\
\hline & $\begin{array}{l}30 \text {-та доба ураження тютюновим димом + } \\
72 \text { год. отруєння натрію нітритом }\end{array}$ & $2,10 \pm 0,14 * * *$ & $3,45 \pm 0,13 * * *$ & $2,05 \pm 0,15 * * *$ \\
\hline \multirow{4}{*}{ Міокард } & Інтактні щури & $3,91 \pm 0,16$ & $4,67 \pm 0,34$ & $4,38 \pm 0,09$ \\
\hline & 30-та доба ураження тютюновим димом & $3,04 \pm 0,13 * * *$ & $2,93 \pm 0,11 * * *$ & $3,23 \pm 0,13 * * *$ \\
\hline & $\begin{array}{l}30 \text {-та доба ураження тютюновим димом + } \\
24 \text { год. отруєння натрію нітритом }\end{array}$ & $2,23 \pm 0,10^{* * *}$ & $2,44 \pm 0,10^{* * *}$ & $2,78 \pm 0,18^{* * *}$ \\
\hline & $\begin{array}{l}\text { 30-та доба ураження тютюновим димом + } \\
72 \text { год. отруєння натрію нітритом }\end{array}$ & $1,92 \pm 0,11 * * *$ & $2,32 \pm 0,13^{* * *}$ & $2,07 \pm 0,14 * * *$ \\
\hline
\end{tabular}

Примітка: див. табл. 1. 
Таблиця 3

Активність аспартатамінотрансферази у сироватці крові (мкмоль/л год.), печінці та міокарді (мкмоль/кг год.) щурів різного віку, уражених натрію нітритом, на тлі 30 -добової інтоксикації тютюновим димом $(\mathrm{M} \pm \mathrm{m}, \mathrm{n}=6)$

\begin{tabular}{|c|c|c|c|c|}
\hline \multirow{2}{*}{$\begin{array}{c}\text { Дослідні } \\
\text { зразки }\end{array}$} & \multirow{2}{*}{ Термін дослідження } & \multicolumn{3}{|c|}{ Групи дослідних тварин } \\
\hline & & статевонезрілі & статевозрілі & cтapi \\
\hline \multirow{4}{*}{$\begin{array}{l}\text { Сироватка } \\
\text { крові }\end{array}$} & Інтактні щури & $0,93 \pm 0,08$ & $0,63 \pm 0,03$ & $0,66 \pm 0,05$ \\
\hline & 30-та доба ураження тютюновим димом & $1,71 \pm 0,11 * * *$ & $1,58 \pm 0,10^{* * *}$ & $1,98 \pm 0,14 * * *$ \\
\hline & $\begin{array}{l}30 \text {-та доба ураження тютюновим димом + } \\
24 \text { год. отруєння натрію нітритом }\end{array}$ & $3,67 \pm 0,09 * * *$ & $2,52 \pm 0,15^{* * *}$ & $2,62 \pm 0,14 * * *$ \\
\hline & $\begin{array}{l}30 \text {-та доба ураження тютюновим димом + } \\
72 \text { год. отруєння натрію нітритом }\end{array}$ & $4,14 \pm 0,13 * * *$ & $3,04 \pm 0,12 * * *$ & $3,30 \pm 0,11 * * *$ \\
\hline \multirow{4}{*}{ Печінка } & Інтактні щури & $4,37 \pm 0,17$ & $4,23 \pm 0,22$ & $4,68 \pm 0,29$ \\
\hline & 30-та доба ураження тютюновим димом & $2,63 \pm 0,13 * * *$ & $2,57 \pm 0,13^{* * *}$ & $3,39 \pm 0,08 * * *$ \\
\hline & $\begin{array}{l}\text { 30-та доба ураження тютюновим димом + } \\
24 \text { год. отруєння натрію нітритом }\end{array}$ & $2,07 \pm 0,10 * * *$ & $1,95 \pm 0,07 * * *$ & $2,35 \pm 0,17 * * *$ \\
\hline & $\begin{array}{l}\text { 30-та доба ураження тютюновим димом + } \\
72 \text { год. отруєння натрію нітритом }\end{array}$ & $1,73 \pm 0,10 * * *$ & $1,67 \pm 0,08 * * *$ & $1,91 \pm 0,15 * * *$ \\
\hline \multirow{4}{*}{ Міокард } & Інтактні щури & $7,45 \pm 0,25$ & $7,37 \pm 0,17$ & $7,23 \pm 0,45$ \\
\hline & 30-та доба ураження тютюновим димом & $6,23 \pm 0,33 * *$ & $5,63 \pm 0,34 * * *$ & $6,00 \pm 0,33$ \\
\hline & $\begin{array}{l}\text { 30-та доба ураження тютюновим димом + } \\
24 \text { год. отруєння натрію нітритом }\end{array}$ & $5,62 \pm 0,33 * * *$ & $4,95 \pm 0,18^{* * *}$ & $5,23 \pm 0,29 * * *$ \\
\hline & $\begin{array}{l}\text { 30-та доба ураження тютюновим димом + } \\
72 \text { год. отруєння натрію нітритом }\end{array}$ & $4,97 \pm 0,37 * * *$ & $4,56 \pm 0,20 * * *$ & $4,75 \pm 0,20 * * *$ \\
\hline
\end{tabular}

Примітка: див. табл. 1.

Дослідження активності аспартатамінотрансферази у міокарді всіх дослідних тварин показало зниження ії в 1,2-1,3 раза після отруєння димом та в 1,5-1,6 раза за одночасного ураження інтоксикованих щурів натрію нітритом.

Результати досліджень дозволили відмітити, що натрію нітрит, потрапивши до організму отруєних тютюновим димом тварин, посилює токсичний вплив останнього. Це підтверджується посиленою генерацією активних форм кисню в нейтрофілах крові, а також посиленням деструктивних процесів у печінці та міокарді, на що вказує підвищена активність амінотрансфераз у сироватці крові та зниження у названих органах. Така зміна активності ензимів свідчить про цитоліз гепато- та кардіоцитів за дії обох токсикантів.

Ми дослідили проникність еритроцитарних мембран після ураження щурів тютюновим димом і в поєднанні з натрію нітритом (табл. 4). Інтоксикація тютюновим димом викликає вірогідне підвищення $(\mathrm{P}<0,001)$ проникності еритроцитарної мембрани щурів статевозрілого та старого віку. Проникна здатність плазматичної мембрани еритроцитів статевозрілих щурів збільшилась на $18,8 \%$, старих - на $12,9 \%$ після отруєння. Натрію нітрит, який отримали токсиковані димом щури, ще більше посилив пропускну здатність еритроцитів, і до кінця експерименту (72 год. ураження натрію нітритом на тлі 30-до-

\section{Таблиця 4}

Проникність еритроцитарної мембрани (\%) у щурів різного віку, уражених натрію нітритом на тлі 30-добової інтоксикації тютюновим димом $(\mathrm{M} \pm \mathrm{m}, \mathrm{n}=6)$

\begin{tabular}{lcc}
\hline \multicolumn{1}{c}{ Термін дослідження } & \multicolumn{2}{c}{ Групи дослідних тварин } \\
\cline { 2 - 3 } & статевонезрілі & статевозрілі \\
\hline Інтактні щури & $20,81 \pm 2,09$ & $17,29 \pm 1,29$ \\
30 -та доба ураження тютюновим димом & $26,04 \pm 2,24$ & $36,04 \pm 2,89 * * *$ \\
30 -та доба ураження тютюновим димом + 24 год. отруєння натрію нітритом & $55,21 \pm 2,34 * * *$ & $46,46 \pm 3,96 * * *$ \\
30 -та доба ураження тютюновим димом + 72 год. отруєння натрію нітритом & $52,46 \pm 2,81 * * *$ & $53,33 \pm 2,18^{* * *}$ \\
\hline
\end{tabular}

Примітка: див. табл. 1.

\section{Таблиця 5}

Вміст молекул середньої маси (фракція $\mathrm{CM}_{254}$ ) у сироватці крові щурів різного віку, уражених натрію нітритом на тлі 30 -добової інтоксикації тютюновим димом $(\mathrm{M} \pm \mathrm{m}, \mathrm{n}=6)$

\begin{tabular}{lcc}
\hline & \multicolumn{2}{c}{ Групи дослідних тварин } \\
\cline { 2 - 3 } Термін дослідження & статевонезрілі & статевозрілі \\
\hline Інтактні щури & $1,40 \pm 0,12$ & $1,10 \pm 0,08$ \\
30 -та доба ураження тютюновим димом & $3,70 \pm 0,11^{* * *}$ & $3,10 \pm 0,11^{* * *}$ \\
30 -та доба ураження тютюновим димом + 24 год. отруєння натрію нітритом & $4,17 \pm 0,06^{* * *}$ & $3,33 \pm 0,10^{* * *}$ \\
30 -та доба ураження тютюновим димом + 72 год. отруєння натрію нітритом & $4,67 \pm 0,07 * * *$ & $3,93 \pm 0,06 * * *$ \\
\hline
\end{tabular}

бового отруєння тютюновим димом) еритроцитарний індекс інтоксикації підвищився в усіх вікових групах: у статевонезрілих щурів - на 31,7\%, у статевозрілих - на $36,0 \%$, у старих - на $23,6 \%$.

Наступний етап досліджень - вивчення вмісту маркерів ендогенної інтоксикації - молекул середньої маси (фракцій $\mathrm{CM}_{254}$ та $\mathrm{CM}_{280}$ ), які у подальшому у разі збільшення їх концентрації в організмі посилюють перебіг патологічного процесу, набуваючи ролі вторинних токсинів, здійснюють вплив на життєдіяльність усіх систем і органів. Показник рівня молекул середньої маси вважають основним біохімічним маркером, що відображає рівень патологічного білкового метаболізму (Nikolsky et al., 2013). Інтоксикація тютюновим димом зумовила збільшення вмісту $\mathrm{CM}_{254}$ у сироватці крові на 30-ту добу отруєння у статевонезрілих і старих щурів у 2,6 раза, у статевозрілих - у 2,8 раза (табл. 5). За комбінованого ураження щурів досліджуваними токсикантами (на 30-ту добу отруєння тютюновим димом і 72 год. застосування натрію нітриту) вміст 3,1-3,3 раза порівняно з інтактною групою тварин. Найвиразнішими виявились зміни цього показника у сироватці крові статевонезрілих щурів (вміст $\mathrm{CM}_{280}$ зазнав найбільшого підвищення в усі терміни дослідження), аналогічні зміни виявлені під час дослідження вмісту фракції $\mathrm{CM}_{280}$ (рис.). $\mathrm{CM}_{254}$ у сироватці крові щурів усіх вікових груп збільшився у

Примітка: див. табл. 1 


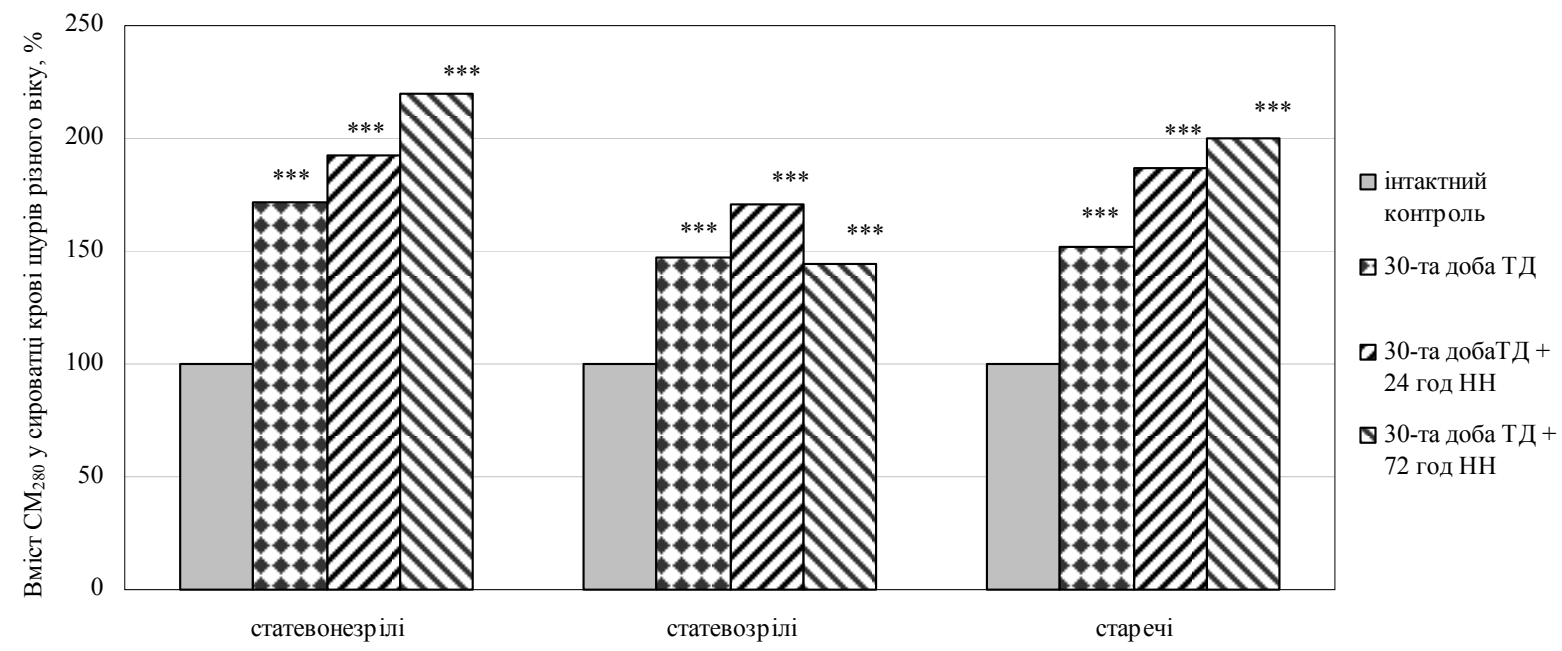

Рис. Вміст $\mathrm{CM}_{280}$ (\%) у сироватці крові щурів різного віку, уражених натрію нітритом, на тлі 30-добової інтоксикації тютюновим димом: *** - вірогідні зміни $(\mathrm{P}<0,001)$ між інтактними щурами та щурами, ураженими токсикантами

Імовірно, підищення концентрації молекул середньої маси у сироватці крові зумовлене порушенням їх елімінації з організму, посиленим утворенням у тканинах або поєднанням обох цих механізмів.

\section{Обговорення}

За дії екстремальних факторів різного походження (хімічне забруднення, іонізуюче випромінювання, гіпер- і гіпоксія, токсичні речовини, запальні процеси) у живих організмів інтенсифікується утворення активних форм кисню (Stangherlin et al., 2009; Wright and Churg, 2010). За певних умов підвищення інтенсивності утворення активних форм кисню над швидкістю їх детоксикації зумовлює пошкодження клітин (Kuznetsov et al., 2011; Wang et al., 2013). За вираженого або тривалого стресу концентрація активних форм кисню у клітині може підвищуватися, та, починаючи 3 певного порогового рівня цих сполук, мобілізація захисних систем клітини слабшає, активуються процеси, які спричиняють апоптоз або некроз (Ozer et al., 2008; Maruschak, 2012).

У щурів різного віку, отруєних натрію нітритом на тлі 30-добової інтоксикації тютюновим димом, у крові вірогідно зростає вміст активних форм кисню. Найвищий вміст агресивних кисневмісних сполук спостерігали у крові статевонезрілих щурів, що може бути пов'язано з неспроможністю ферментних систем цісї групи тварин до знешкодження токсинів та зниження активності процесів адаптації.

Один із проявів токсичної дії метаболітів кисню - інтенсифікація реакцій вільнорадикального окиснення. Активація процесів вільнорадикального окиснення за дії активних форм кисню викликає посилення пероксидного окиснення ліпідів, окисної модифікації білків, деструкції нуклеїнових кислот, вуглеводів, що спричиняє структурні та метаболічні порушення у клітинах. Це може спричинити цитоліз та зміни проникності плазматичних мембран клітин різних органів (Panina et al., 2008; Gladwin et al., 2009).

Найефективніше ступінь ураження клітинних мембран відображається співвідношенням активності внутрішньоклітинних ензимів у клітині та поза ії межами, оскільки в нормі лише незначна кількість внутрішньоклітинних ензимів міститься в сироватці крові. Активність ензимів корелює зі ступенем пошкодження, який може виражатися від патологічного посилення проникності мембрани клітин до некрозу. Найбільшої уваги заслуговують органоспецифічні, або індикаторні ензими, специфічні тільки для певного типу тканин (Tarrant et al., 2013; McGill, 2016).

Дослідження активності амінотрансфераз у сироватці крові щурів після отруєння їх тютюновим димом показало підви- щення аланінамінотрансферази та аспартатамінотрансферази у щурів усіх вікових груп. Ураження, ускладнене дією натрію нітриту, викликало більш виражені зміни активності досліджуваних ензимів у сироватці крові щурів, що може свідчити про значний ступінь цитолізу гепатоцитів і кардіоцитів піля отруєння. Старі щури виявились найчутливішими стосовно цих показників. У печінці та міокарді тварин різних вікових категорій відмічене зниження активності амінотрансфераз після потрапляння натрію нітриту на тлі інтоксикації тютюновим димом, що підтверджує прояв цитолітичного ефекту використаних нами ксенобіотиків.

Для виявлення токсичного впливу активних метаболітів кисню на кров визначено еритроцитарний індекс інтоксикації маркер проникності еритроцитарної мембрани. За дії використаних нами ксенобіотиків збільшується проникність еритроцитарної мембрани, причому використання обох токсикантів одночасно спричинює сумацію їх токсичного впливу. На нашу думку, таке зростання проникності еритроцитарної мембрани може бути однією з причин підвищеного вмісту метгемоглобіну, яке має місце за нітритного ураження та показане нами у попередніх дослідженнях. Одна з причин зміни проникності клітинних мембран за дії натрію нітриту та тютюнового диму токсичний вплив їх метаболітів на структурні компоненти саме мембран (як ліпідні, так і білкові).

Розвиток деструктивних процесів в ураженому організмі спричиняе нагромадження у крові вторинних токсичних продуктів, які утворюються після потрапляння до нього екзогенних токсикантів, і поглиблює ендогенну інтоксикацію (Winchester and Audia, 2006; Panina et al., 2008). У наших експериментах це підтверджується вірогідним збільшенням вмісту в сироватці крові статевонезрілих, статевозрілих і старих щурів молекул середньої маси. Після ураження токсикантами у сироватці крові тварин усіх вікових груп зростає вміст молекул середньої маси обох фракцій $\left(\mathrm{CM}_{1}\right.$ - переважають ланцюгові амінокислоти та $\mathrm{CM}_{2}$ - переважають ароматичні амінокислоти), що може бути наслідком деградації в організмі білкових молекул, гормонів, пігментів, нуклеотидів, зумовленої утворенням значної кількості вторинних токсинів (після активації вільнорадикальних процесів) на тлі потрапляння до організму первинних токсикантів.

Таким чином, виявлені нами метаболічні порушення після отруєння щурів токсикантами ускладнюються одночасним їх впливом на організм. Найбільш виражені зміни спостерігали у щурів статевонезрілого віку.

Отримані нами дані вказують на перспективність подальших досліджень із метою пошуку адекватних методів корекції, які можуть бути використані як із лікувальною, так і з профілактичною метою. 


\section{Висновки}

Ураження щурів натрію нітритом на тлі 30-добової інтоксикації тютюновим димом супроводжується збільшенням концентрації у нейтрофілах крові активних форм кисню. Останні, проявляючи токсичний вплив на різні компоненти мембран і біомакромолекули в організмі, спричиняють зміни проникності мембран гепатоцитів і кардіоміоцитів, а також збільшення проникності еритроцитарних мембран, на що вказує підвищення активності у сироватці крові амінотрансфераз, збільшення еритроцитарного індексу інтоксикації. Нагромадження проміжних токсичних продуктів поглиблює ендогенну інтоксикацію, маркери якої - молекули середньої маси. Їх вміст у сироватці крові вірогідно зростає після ураження натрію нітритом на тлі 30-добової тютюнової інтоксикації. Найчутливіші до дії тютюнового диму та натрію нітриту - статевонезрілі щури. Протягом усього експерименту досліджувані показники саме у цієї групи тварин зазнали найбільших змін.

\section{References}

Baek, J., Zhang, X., Williams, M., Hicks, W., Buehler, P., \& D’Agnillo, F. (2015). Sodium nitrite potentiates renal oxidative stress and injury in hemoglobin exposed guinea pigs. Toxicology, 333, 89-99.

Behera, S., Xian, H., \& Balasubramanian, R. (2014). Human health risk associated with exposure to toxic elements in mainstream and sidestream cigarette smoke. Science of The Total Environment, 472(15), 947-956.

Buehler, P., Butt, O., \& D’Agnillo, F. (2011). Sodium nitrite induces acute central nervous system toxicity in guinea pigs exposed to systemic cell-free hemoglobin. Biochemical and Biophysical Research Communications, 409(3), 412-417.

Churg, A., Cosio, M., \& Wright, J. (2008). Mechanisms of cigarette smokeinduced COPD: Insights from animal models. American Journal of Physiology. Lung Cellular and Molecular Physiology, 294(4), L612-631.

El-Sheikh, N., \& Khalil, F. (2011). L-arginine and l-glutamine as immunonutrients and modulating agents for oxidative stress and toxicity induced by sodium nitrite in rats. Food and Chemical Toxicology, 49(4), 758-762.

Festing, S., \& Wilkinson, R. (2007). The ethics of animal research. Talking Point on the Use of Animals in Scientific Research European Molecular Biology Organization Reports, 8(6), 526-530.

Gladwin, M., Grubina, R., \& Doyle, M. (2009). The new chemical biology of nitrite reactions with hemoglobin: R-state catalysis, oxidative denitrosylation, and nitrite reductase/anhydrase. Accounts of Chemical Research, 42(1), 157-167.

Gross, D., \& Tolba, R. (2015). Ethics in animal-based research. European Surgical Research, 55, 43-57.

Hagstad, S., Bjerg, A., Ekerljung, L., Backman, H., Lindberg, A., Rönmark, E., \& Lundbäck, B. (2014). Passive smoking exposure is associated with increased risk of COPD in never smokers. Chest, 145(6), 1298-1304.

Halima, B., Sarra, K., \& Kais, R. (2009). Indicators of oxidative stress in weanling and pubertal rats following exposure to nicotine via milk. Human and Experimental Toxicology, 29, 489-496.

Ignatowicz, E., Woźniak, A., Kulza, M., Seńczuk-Przybyłowska, M., \& Cimino, F. (2012). Exposure to alcohol and tobacco smoke causes oxidative stress in rats. Pharmacological Reports, 65(4), 906-913.

Ivanov, I., Gluhcheva, Y., Petrova, E., \& Antonova, N. (2014). Hemorheological changes and hematometric erythrocyte characteristics in rats after sodium nitrite intoxication. Korea Australia Rheology Journal, 26(2), 225-228

Jensen, F. (2009). The role of nitrite in nitric oxide homeostasis: A comparative perspective. Biochimica et Biophysica Acta, 1787(7), 841-848.

Kuznetsov, A., Kehrer, I., Kozlov, A., Haller, M., Redl, H., Hermann, M., Grimm, M., \& Troppmair, J. (2011). Mitochondrial ROS production under cellular stress: Comparison of different detection methods. Analytical and Bioanalytical Chemistry, 400(8), 2383-2390.
Luchese, C., Pinton, S., \& Nogueira, C. (2009). Brain and lungs of rats are differently affected by cigarette smoke exposure: Antioxidant effect of an organoselenium compound. Pharmacological Research, 59(3), 194-201.

Maruschak, M. I. (2012). Rol' aktivnikh form kisnyu u rozvitku í progresuvanní gostrogo urazhennya legen' v yeksperimentí [The role of reactive oxygen species in the development and progression of acute lung injury in experiments]. Medical Chemistry, 50, 104-108 (in Ukrainian).

McGill, M. (2016). The past and present of serum aminotransferases and the future of liver injury biomarkers. Experimental and Clinical Sciences International Online Journal for Advances in Science, 15, 817-828.

Nikolaichik, V., Kirkovski, V., \& Main, V. (1989) Sredniye molekuly obrazovaniye i sposoby opredeleniya [Average molecules formation and methods of determination]. Laboratory Work, 8, 31-33 (in Russian).

Ozer, J., Ratner, M., Shaw, M., Bailey, W., \& Schomaker, S. (2008). The current state of serum biomarkers of hepatotoxicity. Toxicology, 245(3), 194-205.

Panina, L., Terletska, S., \& Kovalchuk, S. (2008). Otsinka endohennoyi intoksykatsiyi orhanizmu za umov eksperymental'noyi hemichnoyi hipoksiyi [Evaluation of endogenous intoxication under the experimental hypoxia hemic]. Achievements of Clinical and Experimental Medicine, 2, 72-76 (in Russian).

Pappas, R. (2011). Toxic elements in tobacco and in cigarette smoke: Inflammation and sensitization. Metallomics, 3(11), 1181-1198.

Pickering, A., Vojtovich, L., \& Tower, J. (2013). Oxidative stress adaptation with acute, chronic, and repeated stress. Free Radical Biology and Medicine, 55, $109-118$.

Pikas, O. (2015). Pro stan kurínnya tsigarok u suchasnikh umovakh, yogo vpliv na viniknennya zakhvoryuvan' v organízmí lyudini [On the level of cigarette smoking in modern conditions, its effect on the occurrence of diseases in humans]. Bukovina Medical Journal, 76, 227-230 (in Ukrainian).

Reitman, S., \& Frankel, S. (1957) Definition of biochemical indicators of the toxicity of liver. American Journal of Clinical Pathology, 28(1), 56-60.

Shihadeh, A., Schubert, J., Klaiany, J., Sabban, M., Luch, A., \& Saliba, N. (2015). Toxicant content, physical properties and biological activity of waterpipe tobacco smoke and its tobacco-free alternatives. Tobacco Control, 24(1), 22-30.

Stangherlin, E., Luchese, C., Ardais, A., \& Nogueira, C. (2009). Passive smoke exposure induces oxidative damage in brains of rat pups: Protective role of diphenyl diselenide. Inhalation Toxicology, 21, 868-874.

Tarrant, J., Meyer, D., \& Katavolos, P. (2013). Use of optimized aminotransferase methods in regulated preclinica studies. Veterinary Clinical Pathology, 42(4), 535-538.

Tohaybaev, A., Kurhuzkyn, A., \& Rykun, I. (1988) Metod diagnostiki endogennoy intoksikatsii [Method of diagnosis endohennoy intoxication Laboratory Work, 22-24 (in Russian).

Valavanidis, A., Vlachogianni, T., \& Fiotakis, K. (2009). Tobacco smoke: Involvement of reactive oxygen species and stable free radicals in mechanisms of oxidative damage, carcinogenesis and synergistic effects with other respirable particles. International Journal of Environmental Research and Public Health, 6, 445-462.

Varela-Carver, A., Parker, H., Kleinert, C., \& Rimoldi, O. (2010). Adverse effects of cigarette smoke and induction of oxidative stress in cardiomyocytes and vascular endothelium. Current Pharmaceutical Design, 16, 2551-2558.

Wang, X., Fang, H., Huang, Z., Shang, W., Hou, T., Cheng, A., \& Cheng, H. (2013). Imaging ROS signaling in cells and animals. Journal of Molecular Medicine (Berlin, Germany), 91(8), 917-927.

Westbrook, D., Anderson, P., Pinkerton, K., \& Ballinger, S. (2010). Perinatal tobacco smoke exposure increases vascular oxidative stress and mitochondrial damage in non-human primates. Cardiovascular Toxicology, 10, 216-226.

Winchester, J., \& Audia, P. (2006). Extracorporeal strategies for the removal of middle molecules. Seminars in Dialysis, 19(2), 110-114.

Wipfli, H., \& Samet, J. (2009). Global economic and health benefits of tobacco control: Part 1. Clinical Pharmacology and Therapeutics, 86(3), 263-271.

Wright, J., \& Churg, A. (2010). Animal models of cigarette smoke-induced chronic obstructive pulmonary disease. Expert Review of Respiratory Medicine, 4(6), 723-734.

Yrhashev, T., \& Karimov, A. (2009). Vliyaniye nitratov na organizm cheloveka i zhivotnykh [Effect of nitrates on the organisms of humans and animals]. Nodyr, Dushanbe (in Russian). 